\title{
Uprooting Identity: European Integration, Political Realignment and the Wine of the Languedoc, 1984-2014
}

\author{
Andrew WM Smith \\ University of Chichester, College Lane, Chichester, West Sussex, UK \\ a.smith@chi.ac.uk
}

\begin{abstract}
Uprooting productive vines transformed the landscape of the wine growing Languedoc as part of a coordinated European effort to reduce agricultural overproduction, most notably after 1984. The demographic shifts caused by this transformation upset regional political alliances, coinciding with a socialist presidency and electoral gains for the far-right Front National (FN). More traditional syndical bodies lost their ability to accent national change, floundering in the face of supra-national reform. This left space for political parties to politicise this gap between agency and power, and the FN retooled regional rhetoric emerging from wine protests on the left in service of local campaigns. Contextualising the election of Robert Ménard in Béziers in 2014, this article looks at how sectoral and economic transformation was passed over in favour of populist language borrowed from the vineyards only decades earlier, in which the uprooting of vines explains the perceived uprooting of identity.
\end{abstract}

In January 1984 France took over the presidency of the European Economic Community (EEC). In a summit conducted in the palace of Fontainebleau, President Mitterrand implored his European counterparts to redouble their efforts in securing a unifying treaty which could form the basis of a 'people's Europe' of more effective cooperation. That same year, far from the palace, a sprawling Leclerc supermarket just outside of Carcassonne was torched, razing 3,500 square metres to the ground at the cost of some 30 million Francs. The fires were set with Molotov cocktails thrown by wine growers, furious at further challenges to their livelihood brought about by rhetoric just like Mitterrand's. Here the grand symbols and lofty ideals of European integration met the earthy, rooted rhetoric of agriculture and peasant identity.

These wine growers were part of the Regional Committee for Viticultural Action (Comité Régional d'Action Viticole; CRAV), representing an armed wing of the Languedoc wine growers' syndical movement, with a loose, episodic presence that made itself felt 'when the situation was blocked'. ${ }^{1}$ Formed in 1961 by young veterans of France's Algerian War, they drew their heritage from the great revolt of 1907 , in which the entire region had risen in protest against devastating market downturns and suspicions of fraud. $^{2}$ Throughout the 1970s they undertook small-scale guerrilla attacks against the state's infrastructure in a period of near open revolt. ${ }^{3}$ In February 1983, for example, around 200 vignerons gathered at Béziers station and stopped the Talgo train, which travelled between Barcelona and Geneva. ${ }^{4}$ They sprayed it with slogans protesting against the EEC: 'it's not by accident that we have stopped an international train. It's a message opposing Spanish entry into the Common Market'.

\footnotetext{
1 ‘Comité d'action viticole: 'Il faut plus que des promesses', La Dépêche, 20 June 1983, Archives Départmentales de l’Aude [hereafter ADA] 98J15.

2 Andrew WM Smith, Terror and Terroir: The Winegrowers of the Languedoc and Modern France (Manchester: Manchester University Press, 2016), 21-45.

3 Ibid, 109.

4 CRS Radio Message Transcript, 15 Feb. 1983, Archives Départmentales de l'Hérault [hereafter ADH] 1719W144.

(C) Cambridge University Press, 2020
} 
Courting regionalist support, they also sprayed the train with the Occitan cross, combining a rejection of European expansion with an articulation of regional identity. ${ }^{5}$

The CRAV tilted at windmills in resisting attempts by the French government or the EEC to reshape the region. As part of its engagement with the Common Agricultural Policy in the 1980s, France was signed up to a fund called the PAD (primes d'arrachage definitive), which paid wine growers to uproot productive vineyards to reduce overproduction. Wines became less central to the region's employment and 1984 opened a story about the Languedoc's changing spatial politics, wherein physical changes to the landscape (with around 150,000 hectares of vineyard uprooted across the Languedoc between 1976 and 2000) shook up traditional political loyalties. ${ }^{6}$ Yet, for all that the CRAV failed to halt imports or uprooting programmes, they highlighted a disjuncture of power and agency between the region and a supranational entity like the EEC, via the French nation state. This developing trend helps to contextualise the election of a Front National (FN) mayor thirty years later in 2014 in the heartland of the traditionally socialist wine growing south (midi viticole), Béziers. $^{7}$

The decline of the wine industry and Béziers's concomitant loss of economic and social status within the region ingrained a sense of decline and neglect in civic politics, and the FN mayor Robert Ménard goaded existing cultures of opposition into a broader rejection of the complex, distant and unpalatable language of the central state. Regional discourse from wine protests on the left was reused in service of the local FN campaign, retooling criticism of impersonal power and demonstrating agency with securitised rhetoric and strongman municipal policies. ${ }^{8}$ As elsewhere, this FN municipal victory was not simply a 'cultural backlash' against immigration, the left or liberal republican democracy, but also a retrenchment of conservative protectionist values in the face of economic marginalisation, couched in the language of past regional struggles. ${ }^{9}$

This article will first examine how state policies to alter the structures of wine production affected the Languedoc, in order to show how those affected by the changes came to associate national policies with new European priorities. It will explore the shift in long-standing political allegiances brought about by changing the focus of protest from Paris to Brussels and altering the spatial and demographic realities of the region. This piece argues that the shifting scales of agency and identity between Europe, the nation state and the region were distorted by rhetorical strategies that relied on juxtaposing rooted, local identity against abstract notions of external power. In the second section, this article will show how the adaptable symbols of past struggles were retooled for contemporary political phenomena by focusing on the city of Béziers as a case study. Against this background, political developments in Béziers were determined by broader sectoral and demographic change associated both with Paris and Brussels, yet driven by fears that any such outside pressure was causing the identity of wine

\footnotetext{
5 'Vignerons: Opération Talgo', Indépendant, (16 Feb. 1983), ADA98J19.

6 Alun Jones and Julian Clark, 'From Filière to Territoire: Changing Rural Policy in the Languedoc', Modern \& Contemporary France, 11, 3 (2003), 336. See also Pierre Bartoli, La Régression Viticole en Languedoc (Montpellier: INRA-ENSA, 1985).

7 See Jérôme Fourquet and Sylvain Manternach, 'Vendanges présidentielles: éléments pour une géographie électorale du vignoble français', IFOP focus, 183 (2018), 13-8.

8 This is consistent with the broader platform of the FN nationally. See Jens Rydgren, 'France: The Front National, Ethnonationalism and Populism', in Daniele Albertazzi and Duncan McDonnell, eds., Twenty-First Century Populism (Palgrave Macmillan, 2008), 166-80; Aurelien Mondon, 'Populism, The "People" and the Illusion of Democracy The Front National and UKIP in a Comparative Context', French Politics 13, 2 (2015), 141-56.

9 For discussion of the broader trend, see Andres Rodríguez-Pose, 'The Revenge of the Places that Don't Matter (and What to do About It)', Cambridge Journal of Regions, Economy and Society, 11, 1 (2018), 189-209; Oliver Kuhn, 'Liberal Universalism in Crisis - The Nationalist Populist Challenge of Transnational Political Standards', Transnational Social Review, 8, 3 (2018), 1-14; Jürgen Essletzbichler, Franziska Disslbacher and Mathias Moser, 'The Victims of Neoliberal Globalisation and the Rise of the Populist Vote', Cambridge Journal of Regions, Economy and Society, 11, 1 (2018), 73-94; Ian Gordon, 'In What Sense Left Behind by Globalisation? Looking For a Less Reductionist Geography of the Populist Surge in Europe', Cambridge Journal of Regions, Economy and Society, 11, 1 (2018), 95-113.
} 
growers to be uprooted along with the region's vines. Given the symbolic qualities of wine to French national identity, and the centrality of wine to the economic and cultural life of the Midi, reforms to the sector were read as (and could be presented as) much more significant political interventions in people's sense of self and place. As shown in the Languedoc, the interaction of wine and politics, often heated in France more broadly, could with only a little encouragement become explosive.

\section{Europe, Wine Growers and Political Realignment}

In 1984 many of the pressures facing the wine growing Languedoc came to a head. The EEC Dublin Summit (4-11 December 1984) set limits on agricultural overproduction (including wine) in advance of the accession of Spain and Portugal in 1985. Each member country was assigned a production quota, beyond which wine would be distilled at near production cost. Likewise, an adjustment of the reimbursements for uprooting vines induced many wine growers to uproot with the promise not to replant. Surplus production owing to mechanisation, productive (often low-quality) varietals of grape and the abundant southern sun all ensured that the Languedoc had long been France's biggest producer of wine by volume (around 35 per cent of French volume and 5 per cent of global volume in 1975). ${ }^{10}$ Declining French wine consumption (from 126.1 litres per year to 63.9 litres per year between 1961 and 2001) meant that large volumes of low quality wine remained unsold every year, requiring emergency distillation (usually funded by subsidy) to clear the market between seasonal harvests. ${ }^{11}$ The Midi was a prime target for making good French international commitments to reduce volume. ${ }^{12}$ Over the next three seasons 20,000 hectares would disappear from the Languedoc-Roussillon, in addition to the 34,000 hectares already uprooted between 1976 and $1985 .{ }^{13}$ For wine growers firmly rooted in the social fabric of the region, accepting money from government or European technocrats to uproot their vines became associated with the physical uprooting of wine growers from the region, eroding regional and occupational identity alongside the economic potential of the Languedoc.

Historian Geneviève Gavignaud-Fontaine described the decisions in Dublin as sounding like 'the strains of a funeral march' to Languedoc wine growers. ${ }^{14}$ Yet, the CRAV raged against the dying of the light and targeted European wine imports. They intercepted trucks and tankers on 12 to 17 January in the Aude, ${ }^{15}$ seizing 8,000 hectolitres of Italian wine destined for merchants and emptying it into a nearby stream. ${ }^{16}$ Attacks and demonstrations continued over the next few months, as high expectations met with frustration. Then, just outside Carcassonne at 10pm on 20 April 1984, around 100 of these 'wine commandos' gathered in the car park of a Leclerc supermarket. ${ }^{17}$ They smashed windows with iron bars and set the supermarket ablaze with a volley of Molotov cocktails. ${ }^{18}$ The next morning, as the building still smouldered, politicians and police mobilised to condemn the

10 For a detailed discussion of the Dublin Accords, see Andy Smith, 'Beyond 'Connections in Brussels': The Multi-Level Representation of Agriculture in Two French Regions', paper presented at European Union Studies Association Conference, held in June 1999; Yves Le Pape, Andy Smith, 'Décentralisations et agriculture: analyse comparée de deux régions français', Politiques et management politiques, 16, 4 (1998); Marielle Berriet, Alain Faure, William Genieys, Andy Smith, Le Languedoc-Roussillon et les politiques communautaires agricoles et rurales, (FAIR/DGVI research report, December 1998). Andy Smith, 'L'Europe, le Midi et le vin', Pôle Sud, 9 (1998), 125-35. Pierre Bosc, Le vin de la colère (Paris: Galilée, 1975), 37.

11 See Jean-Marc Touzard, Jean-Pierre Laporte, 'Deux décennies de transition viticole en Languedoc-Roussillon', Pôle Sud, 9 (1998), 26-47; Smith, Terror and Terroir, 207.

12 Yves Gilbert, Le Languedoc et ses images (Paris: L'Harmattan, 1989), 40.

13 Jacques Rouzier, Le Languedoc-Roussillon 1950-2001 (Toulouse : Privat, 2002), 79.

14 Geneviève Gavignaud-Fontaine, Le Languedoc viticole, la méditerranée et l'Europe au siècle dernier (Montpellier: Presses Universitaires de la Méditerranée, 2006), 406.

15 'Une citerne vidée', L'Indépendant (13 Jan. 1984); 'Retour à la colère', L'Indépendant (18 Jan. 1984), ADA98J15.

16 'Manifestation . . . et concertation', Le Paysan du Midi (16 Feb. 1984), Archives Départmentales du Gard JR438-33.

17 Gavignaud-Fontaine, Le Languedoc viticole, 402.

18 Laurence McFalls, In vino veritas: Professional Ideology and Politics in Viticultural Languedoc, 1907-87, Ph.D. thesis, Harvard University, 1989, 249-50; Bernard Revel, Montredon: les vendanges du désespoir (Portet-sur-Garonne: Loubatières, 1996), 319-20 ; Gilbert, Le Languedoc et ses images, 45. 
culprits. Raymond Chésa, Mayor of Carcassonne since 1983, warned: 'after the events this town has witnessed, I'd say the climate of insecurity is a prelude to civil war'. ${ }^{19}$ The reaction from Edouard Leclerc - the proprietor of the supermarket chain - was equally damaging. He claimed that in all their 450 stores around France, 25 per cent of wine sold came from the Aude, whilst only 0.1 per cent of wine came from outside France. In destroying the Carcassonnais store, the CRAV had cut off one of the principal distributors of Audois wine, a fact only exacerbated by the chain's boycott of Audois wine for a month following the attack. ${ }^{20}$

The choice of target and the scale of damages affected the CRAV's credibility as an acceptable interlocutor, and amidst a broader push to modernise the sector, support for militant wine growers among regional political elites was undermined. ${ }^{21}$ Laurence McFalls describes their marginalisation in these terms:

Abandoned by their party, the wine growers of the Midi found themselves with a choice. They could rally to the old professional defence movement $-\ldots$ which maintained the tired discourse of unity and continued to maintain that an alternative was possible - or they could stay loyal to the Socialist Party and adapt to their new liberal, pro-European policies. ${ }^{22}$

For wine growers these new policies largely meant the 'poisoned chalice' of uprooting vines, reducing quantity and increasing quality. ${ }^{23}$ Declining domestic wine consumption harmed the market for the bulk wines of the Languedoc and the old means of extracting concessions from the state to mitigate this were disappearing. For wine growers, and indeed for the state, foreign scapegoats (whether they be Brussels bureaucrats or Spanish wine makers) were ever more enthusiastically blamed for the sector's seemingly intractable decline. As Gavignaud-Fontaine observed, 'within two generations and less than fifty years, this wine growing society imploded'. ${ }^{24}$

The Socialist Party's (Parti Socialiste; PS) shift towards a more technocratic, depoliticised form of economic policy was confirmed after its early 'state of grace' ended along with its first year in the presidency in June $1982 .{ }^{25}$ Beset by the need to devalue the franc within the European Monetary System (EMS) for the second time, Mitterrand was presented with two options by March 1983: to leave the EMS and follow protectionist policies, or commit to Europe and remain within the EMS on what domestic critics decried as 'narrow Ordo-liberal terms'. ${ }^{26}$ Mitterrand, who had tended to represent the Socialist Party's 'pro-integrationist' wing since 1971, chose to commit to Europe. ${ }^{27}$ This pushed the PS into conflict with some traditional supporters, and there was political headway to be made for parties and politicians all-too-willing to seek to politicise the failures of this generalised policy

19 Revel, Montredon, 320.

20 'Carcassonne: Les 'casseurs' de Leclerc arrêtés aujourd'hui?', La Dépêche, 25 Apr. 1984. ADA98J21.

21 The CGVM was increasingly supplanted by the FNSEA, for example. See Andrew WM Smith, “Je suis socialiste et quinziste": Rugby, Wine and Socialism in the Aude since 1976', National Identities, 16, 4 (2014), 291-309; Jean-Philippe Martin, Histoire de la nouvelle gauche paysanne, Paris: La Découverte, 2005), 277; Jean-Philippe Martin, 'Confédération paysanne et tradition viticole en Languedoc-Roussillon', Pour, 196-7, 1 (2008), 295-301.

22 Laurence McFalls, 'Effets discursifs, politiques et pratiques de la révolte de 1907, ou Grandeur et misère du socialisme viticole dans l'Aude', unpublished paper sent on by author, 13-4.

23 '1,500 viticulteurs des Corbières se sont rassemblés mardi soir à Saint-Laurent-de-la-Cabrerisse', Midi Libre, 9 Mar. 1967, ADA31J20. For more on how lobbyists pushed the state towards an emphasis on quality over quantity (and campaigned for lower rates of consumption), see Joseph Bohling, The Sober Revolution: Appellation Wine and the Transformation of France (Ithaca: Cornell University Press. 2018).

24 Geneviève Gavignaud-Fontaine, 'L'extinction de la “viticulture pour tous” en Languedoc, 1945-1984', Pôle Sud, 9 (1998), 64.

25 Alistair Cole, 'A House Divided: Socialism à la française', in Gino Raymond, ed., France in the Socialist Years (Aldershot: Dartmouth, 1994), 68-70.

26 Ben Clift, French Socialism in a Global Era: The Political Economy of the New Social Democracy (London: Continuum, 2005), 139-40; Alain Bergounioux, Gérard Grunberg, L'ambition et le remords: les socialistes français et le pouvoir (Paris: Fayard, 2005), 327-61; Philippe Moreau-Defarges, 'La France et l'Europe, l'inévitable débat', Politique étrangère, 67, 4 (2002), 951-66; Jean-Pierre Chevènement, La France est-elle finie?, (Paris: Fayard, 2011).

27 Helen Drake, 'François Mitterrand, France and European Integration', in Raymond, France in the Socialist Years, 34, 38-9. 
shift. During this period of left-wing government, anti-system votes fled to the margins, and the former southern strongholds of the PS and the French Communist Party (Parti Communiste Français; PCF) suffered. In the Midi, as Touzard notes, this politicisation of the margins occurred using 'shared symbolic references that blended sector and region (the 1907 movement, the defence of southern wine growing, Occitanie) and identified external enemies: Italian imports, merchants, technocrats from Brussels and the government'. ${ }^{28}$

This was set against the increasing national success of the FN, which since its inception in 1972 had become less of a marginal group and more of a partisan presence on the political spectrum. ${ }^{29}$ If we acknowledge the short-term roots of the CRAV in the social impact of the Algerian War (and its longer-term roots in the defence of the wine industry and Occitan identity), then it is perhaps interesting to see the way in which this blurred boundaries in a region where resentment of Algeria was never far away (whether for wine imports specifically or North African immigration more broadly). The FN stood Andre Troise, a gun-toting ex-OAS activist with an extreme stance on immigration who seemed to make no effort to appeal to wine growers, in the 1973 legislative elections in Montpellier and took just over 4 per cent of the vote. ${ }^{30}$ When Marie-Claude Pelletier stood in the 1978 Legislative elections in the Montpellier-Lodève constituency, she tried addressing wine growers directly, alongside traditional demands to protect family units and halt immigration. Lamenting the economic crisis, and exhibiting a whiff of nostalgérie (a pining for France's occupation of Algeria), Pelletier identified the two groups most needing defence as wine growers and those who had returned from Algeria (rapatriés). ${ }^{31}$ Adopting regional rhetoric helped, and by 1988 Troise's vote had doubled to 8 per cent when he stood in Béziers. ${ }^{32}$

The European elections of 1984 caused a national shock when the FN gained 11.2 per cent of the vote. Only two years later the party won nearly 10 per cent of the votes in the legislative elections, gradually eroding the established base of the Socialist Party in Languedoc-Roussillon. ${ }^{33}$ This is not to suggest that the FN enjoyed a meteoric rise, nor uninterrupted progress, nor indeed that the PS and PCF disappeared from the map, as we shall see. There was, however, an upheaval in political loyalties and a significant spike for the FN around 1986, when Mitterrand's reintroduction of proportional representation for the legislative elections provoked accusations he was strengthening the FN to spite Jacques Chirac's centre-right coalition. In the Languedoc, the FN succeeded not where immigration was highest but rather in the countryside where it was minimal. Wealthier 'appellation' growers (usually independent proprietors producing quality wines) tended to vote further to the right, as in Pinet in the Hérault, where Le Pen won 19.2 per cent of the vote in the 1992 Presidential election. ${ }^{34}$ Elsewhere, votes came from the expanding suburbs of Béziers and urban centres, where less secure and

28 Touzard, 'Regulation sectorelle', 318.

29 Guy Birenbaum, 'Les stratégies du Front National (mars 1986-mai 1987)', Vingtième Siècle, 16 (1987), 3.

30 Legislative election results by circonsription (First round, 4 Apr. 1973). Retrieved from https://www.data.gouv.fr/s/ resources/elections-legislatives-1958-2012/20150206-165729/cdsp_legi1973t1_circ.csv on 2 July 2018.

31 Meaning those returned from Algeria after the declaration of Independence. Election Material, Legislative Elections [hereafter EMLE] 1973 (Hérault, 2eme circonscription) Retrieved from https://archive.org/details/archiveselectoralesducevipof on 2 July 2018. See also, Jean-Baptiste Forray, Les Barons: Ces élus qui osent tout! (Paris: Flammarion, 2014), Chapter 1.

32 Legislative election results by circonsription (First round, 5 June 1988). Retrieved from https://www.data.gouv.fr/s/ resources/elections-legislatives-1958-2012/20150206-165753/cdsp_legi1988t1_circ.csv on 2 July 2018. EMLE 1973 (Hérault, lere circonscription). Retrieved from [https://archive.org/details/archiveselectoralesducevipof], on 29 June 2018. J. Collado, 'À Béziers, ils résistent encore et toujours à Robert Ménard', Slate.fr, 7 May /2015. Retrieved from http://www.slate.fr/story/101243/Béziers-Ménard-opposition-citoyens on 2 July 2018.

33 Alexandre Dézé, Le Front national: a la conquête du pouvoir? (Paris: Armand Colin, 2012), 75; Hans-Georg Betz and Stefan Immerfall, eds., The New Politics of the Right (London: MacMillan, 1998), 13; Emmanuelle Reungoat, 'Le Front National et l'union européenne. La radicalisation comme continuité, Sylvain Crépon, Alexandre Dézé and Nonna Mayer, eds., Les faux-semblants du Front national (Paris: Sciences Po, 2015), 228; Daniel Stockemer, The Front National in France: Continuity and Change Under Jean-Marie Le Pen and Marine Le Pen (Springer: Cham, 2017), 16.

34 Christophe Arpaillange \& Jean-Paul Cheylan, 'Les élections de mars 1992 en Languedoc-Roussillon', Pôle Sud, 2 (1995), 36. 
less attractive employment filled the gaps left by the decline of mass wine growing. It seemed for many that the extreme right offered the potential for dramatic change previously owned by the left. ${ }^{35}$ On the right, Jacques Blanc (Union for a Popular Movement; Union pour un Mouvement Populaire; UMP), gained a majority by relying on the votes of the FN in his election to president of the region, illustrating a different sort of 'cohabitation' in the south that seemed to signal the FN's partial political normalisation. $^{36}$

The political blurring that boosted the FN can be seen in the radical wine growers' regional press. The first issue of the socialist Occitan journal, Volem Viure al Pais, carries an article from a young Robert Ménard (just after an interview with a leading militant wine grower, Michel Romain), calling for action to promote environmental conservation in the face of industrial development. ${ }^{37}$ Ménard's own trajectory from the orbit of the left in the 1970s towards the radical right is useful here, as it illustrates how the issues of identity and landscape drew people away from the traditional strongholds of the red south (midi rouge) as we shall see. This is also the case for the Echo des Corbières, a bastion of left-wing militancy throughout the 1970s until it faltered as the wine grower's movement stuttered. The Echo du Languedoc, the paper's successor, which began publishing in 1990, signalled something of the shift in the political base of radical wine growers. Wine growing leader Emmanuel Maffre-Baugé, a communist European Parliament member from 1979 to 1989, praised the paper's 'verve and fine caustic spirit' as it 'knew how to hold its head high' in defence of regional interests. ${ }^{38}$ Headed by Henri Fabre-Colbert (an Occitaniste writer with a proud resistance history in the Francs-Tireurs et Partisans; FTP), ${ }^{39}$ the relaunched newspaper was much freer in its political loyalties than the movement had been in in the 1970s, and each issue carried a 'forum of ideas' which invited all political parties to address its regional readership. ${ }^{40}$ One correspondent expressed concern about this section and the wisdom of freely publishing the views of 'a fascist party like that of Le Pen'. ${ }^{41}$ In response Fabre-Colbert claimed there was no distinction in the freedom of the press, and that the journal defied 'an era in which the laws of exclusion have never been more numerous' ${ }^{42}$ Yet other correspondents queried why, despite Fabre-Colbert's protestations of openness and diversity, the journal seemed so particularly friendly to the $\mathrm{FN} .{ }^{43}$

Their continuing predominance provides useful material for understanding the construction of the FN's appeal in the Languedoc. ${ }^{44}$ One of the journal's most active political correspondents, hailing from the FN, was Henri Escortell, a pied-noir resident in Carcassonne since $1962 .{ }^{45}$ He was the founder of the Carcassonne section of the FN in 1983, and elected a Conseiller Régional in March 1992. ${ }^{46}$ In his letters to $L$ 'Echo, Escortell speaks of wine growers being manipulated by the left, just as the right manipulated northern farmers. Lamenting the profession's perilous state, he offered a tonic: 'what the peasants want is to remain proud of their independence and their culture'. ${ }^{47}$ Local issues were

35 Marie-Claire Bernard \& Pierre Carrière, 'Le Rassemblement National en Languedoc-Roussillon aux élections de 1986', Espace, populations, sociétés, 3 (1987), 497-509.

36 Gilbert, Le Languedoc et ses images, 219; Birenbaum, 'Les stratégies du Front National', 3-20.

37 Robert Ménard, 'Pas ne nouveau Seveso á aucun prix', Volem Viure al Pais, 1 (1978). Lo Cirdoc [hereafter LC].

38 'Quelque mots de MAFRE-BAUGE', L'Echo du Languedoc, 10 (1990). LC.

39 'Conilhac-Corbières. Hommage à Fabre-Colbert', La Dépeche, 1 June 2010.

40 'Forum aux idées', L'Echo du Languedoc, 1 (1990). LC.

41 P. Brunet Borel, 'La liberté ne se découpe pas en tranches', L'Echo du Languedoc, 6 (1990). LC.

42 'Réponse (exceptionnelle) de l'Echo', L'Echo du Languedoc, 6 (1990). LC.

43 'Si je mords je veux commentaires', L'Echo du Languedoc, 15 (1991). LC.

44 Fabre-Colbert elsewhere critiques the 'progressive neurosis' afflicting the country, while roundly dismissing the project of European integration as futile and exploitative. See Henri Fabre-Colbert, La St Con (Lezignan: Imprimerie Lézignanniase, 1993).

45 EMLE 1988 (Aude, lere circonscription). Retrieved from https://archive.org/details/archiveselectoralesducevipof on 29 June 2018.

46 EMLE 1993 (Aude, lere circonscription). Retrieved from https://archive.org/details/archiveselectoralesducevipof on 29 June 2018.

47 Henri Escortell, 'Le Front National parle du poids des paysans', L'Echo du Languedoc, 1 (1990). LC. 
leveraged to support a narrative of betrayal by government, as with the exaggerated outrage when the bulletin of the Aude's general council adorned its front page with the ill-chosen picture of a smiling young man eating a hamburger with a coca-cola at hand. ${ }^{48}$ 'Audois wine growers, open your eyes', shrieked Escortell, 'you were forgotten, despised before 1981 and deceived thereafter; your dignity demands - and especially in the Aude - that this scandalous political class and their accompanying affairs be chased, and that they be held account for their lies and deceptions' ${ }^{49}$ His reaction to a hamburger on a magazine cover may have been overboard, but it illustrated the contours of this flexible narrative of local disaggregation from national left-wing political elites that gathered pace in the early 1980s, with the FN beginning to figure more clearly on the political landscape. The 'shared symbolic references ${ }^{50}$ of past struggles were capitalised upon by parties keen to politicise the hardships associated with sectoral transformation and national political realignment.

\section{Béziers: From Productivism to Populism?}

In Béziers, the former wine growing capital of the south (midi viticole), the effects of uprooting and sectoral change could be seen acutely. Between 1988 and 2007, the Languedoc had grown in population faster than the national average ( 1.4 per cent per year as opposed to 0.6 per cent nationally), concentrated around the suburban areas of its major cities and along the coast. ${ }^{51}$ Béziers as a city, however, saw another trend. As mass wine growing declined, so did its own status in the region, and its population, together with the uprooting programmes led by the EEC and French government, profoundly changed the landscape of the Hérault, especially around Béziers. ${ }^{52}$ In 1975 the city had had a recorded population of 83,994 , yet by 1999 it had shrunk to 69,359 , a loss of nearly 15,000 people. ${ }^{53}$ Unemployment in the Languedoc also remained higher than the national average, with the rate in the Hérault rising from 8.1 per cent in 1980 to 13.8 per cent in $1990 .^{54}$ That level would continue to remain high, at 12.2 per cent in 2002 and 13.7 per cent in $2012 .^{55}$ This economic and demographic transformation created a tangible 'sense of decline', and its city-centre in particular suffered an exodus. ${ }^{56}$ Increasingly, families moved to the suburbs, and young people were drawn away by the promise of Montpellier's vibrancy and development in contrast to Béziers's faded glory.

National elections can help contextualise these developing political trends in the Languedoc. Between 2010 and 2012 the FN made inroads into smaller communes, more than doubling their vote share in rural communes with up to 500 voters. ${ }^{57} \mathrm{~A}$ declining population and exasperation with the 'loss of rural identity' eroded the base of the left in the countryside, marked especially by changes in viticultural structures that altered the long-term demographic outlook. ${ }^{58}$ The beneficiaries

\footnotetext{
48 'La Gaffe', 'Viticulteurs ouvrez les yeux', L'Echo des Corbieres, 16 (1991). LC.

49 H Escortel, 'Viticulteurs ouvrez les yeux', L'Echo des Corbieres, 16 (1991). LC.

50 Touzard, 'Regulation sectorelle', 318.

51 Emmanuel Négrier, Marie-Thérèse Jourda, 'Trajectoires politiques en Languedoc électoral (1988-2008)', Pôle Sud, 29, 2 (2008), 59.

52 See Clément Arnal, Lucette Laurens et Christophe Soulard, 'Les mutations paysagères engendrées par l'arrachage viticole, un vecteur de mobilisation des acteurs territoriaux dans l'Hérault', Méditerranée. Retrieved from http://mediterranee. revues.org/6673 on 6 Dec. 2013.

53 Corinne Escaffit, Emmanuel Négrier, "Chapitre 7. Béziers. Naissance d’un fief», in Bernard Dolez et al, Le vote des villes (Paris: Presses de Sciences Po, 2002), 125-38.

54 'Eléments pour un diagnostic prospectif du Languedoc-Roussillon', Groupement de la Statistique Publique Languedoc-Roussillon, Préfecture de la région Languedoc-Roussillon (2007); Sylvie Dumartin, 'L'évolution du taux de chômage dans les départements de 1987 à 1990', INSEE Premiere, 154 (1991).

55 INSEE, 'Analyse Languedoc-Roussillon-Midi-Pyrénées', 26 (2016), supplementary statistics for Hérault. Retrieved from https://www.insee.fr/fr/statistiques/2128959 on 2 Aug. 2018.

56 Escaffit, Négrier, 'Béziers. Naissance d'un fief ?', 125.

57 Sylvain Barone and Emmanuel Négrier, 'Voter Front National en milieu rural. Une perspective ethnographique', in Crépon et al., Les faux semblants, 420.

58 Négrier and Jourda, 'Trajectoires politiques en Languedoc', 61; Sylvain Barone and Emmanuel Négrier, 'Voter Front National en milieu rural. Une perspective ethnographique', in Crépon et al., Les faux semblants, 434.
} 
of this demographic shift were the suburbs. Yet, these burgeoning suburban populations saw the emergence of what Jean Viard calls 'commuter democracy', as voters favoured policies that addressed domestic issues over employment, looking for representation in the suburbs in which they lived and not the cities where they worked: 'local democracy is commuter democracy, against development, against immigration, and where local elites become conservative by dint of events' ${ }^{59}$ Coastal constituencies were also more likely to turn to the right, playing to the theme of a 'property owning France' and the attendant sympathy for securitised social policy served up by the right. These trends of securitisation and conservative property holders privileged the political inheritance of Poujadism, whose programme had historically found sympathy in the Hérault. ${ }^{60}$

Changes to the region's political compact were underlined during a wine growers' demonstration in Béziers on 6 February 1992. Motivated by perceived fraud, the protest quickly escalated after a confrontation between the socialist Mayor of Béziers Alain Barrau and CRAV member Michel Bataille over the government's muted response to fraud. Fifty or so 'wine commandoes' in balaclavas clashed with police, and several CRAV members were seized as police were ordered to 'arrest the masks'. ${ }^{61}$ These activists seemed increasingly isolated from their base and, in their masks, increasingly unaccountable. Things worsened over that summer, culminating in a series of bombings of government buildings, with police Colonel Weber declaring that 'there [was] manifestly wine terrorism' at work in the Languedoc. ${ }^{62}$ The label of terrorists seemed to finish off any credibility the CRAV had retained as a voice of the wine growing masses that nevertheless supported an integrative republican message and engagement with the Socialist Party. When that relationship was stripped away, those dissatisfied with government and angry at their ill fortune were forced to forge new political alliances that lacked the same storied history.

National newspapers commented on the 'disintegration of Héraultais socialism' and the separation of the left from its regional base in the wine growing south (midi viticole), a blow to Alain Barrau which eventually saw him replaced as mayor of Béziers. ${ }^{63}$ In the election of June 1995 the centre-right Raymond Couderc beat Barrau, denouncing him as a 'hostage to the communists' on a shared PS-PCF list, whilst also highlighting his inability to get results for the town's interests. ${ }^{64}$ The communists had lost some of their 'anti-systemic' appeal by participating in the Mauroy government, and this was true also in the municipal elections. ${ }^{65}$ Couderc, standing on a broad centre-right ticket, remained mayor of Béziers from 1995 until 2014, surviving challenges from the left during that time in Jean-Claude Gayssot (a transport minister under Lionel Jospin), and the socialist Jean Michel du Plaa. In the context of broader political realignment, Couderc's tenure bridged this transition period, as the socialists lost their hold on the region's loyalties.

Uprooting had transformed the wine sector and the outlook remained difficult, drawing further protests against European integration and the opening up of the wine market. In 2000 Jean Huillet spoke of 'the seeds of a developing crisis for the cooperative wine growers of the Hérault' after a series of commando actions against government office buildings and tollbooths. ${ }^{66}$ As these protests continued in 2001, syndical leaders led marches and protests, ranging diatribes against 'the French

\footnotetext{
59 Jean Viard, Alice Béja and Olivier Mongin, 'Marseille, Maritime Et Cosmopolite', Esprit, 395, 6 (2013), 91. See also Jean Viard, Elogé de la mobilité (Paris: Aube, 2014); Pascal Perrineau, La France au Front (Paris: Fayard, 2014), 154-6.

60 Jim Shields, The Extreme Right in France (New York: Routledge, 2007), Chapter 3. This also tied into the FN's appeal as a 'descendant of Poujadism'. Mathias Bernard, Les Années Mitterrand (Paris: Belin, 2015), 94.

61 'Francisation de vin', Midi Libre, 6 Feb. 1992; 'Le vin coule à Béziers...', Midi Libre 7 Feb. 1992; 'Deux viticulteurs interpellés', Dépêche, 07 Feb. 1992. ADA 98J15.

62 'Le CAV embrase l'Aude et l'Hérault', L'Indépendant, 30 May 1992. ADA 98J15.

63 Barrau himself owned a vineyard in Thézan. 'Les résultats du premier tour des élections législatives Languedoc-Roussillon (21)', Le Monde, 23 Mar. 1993; Benoit Hopkin, 'Le Midi " rouge " risque de basculer à l'extrême droite', Le Monde, 8 June 2002.

64 Gilbert Laval, 'A Béziers, c'est la mêlée ouverte. La droite mobilise deux listes pour ravir la ville au maire PS', Liberation, 8 June 1995.

65 Rydgren, 'France: The FN, Ethnonationalism and Populism', 177

66 Christian Goutobre, 'Le coup de sang des viticulteurs en colère', La Dépêche, 2 Aug. 2000.
} 
government and the community regime in Brussels' ${ }^{67}$ 8,000 wine growers blocked the roads in protest, and elected officials were amongst them; Christian Pélagatti, deputy mayor of Béziers, told reporters that 'this viticultural crisis, whose effects are beginning to be felt, will have dramatic effects on the local economy of Béziers'. ${ }^{68}$ Over 7,000 protested along the Allées Paul-Riquet, with violent clashes with the police's Republican Security Companies (Compagnies républicaines de sécurité; CRS) and commando actions against suppliers, as spokesmen cried that 'since 1907, nothing has changed!'69 Signs of the FN's attempts to appeal to this growing dissatisfaction can be seen in the unsuccessful mayoral campaign run by Francine Lopez-Commenge, who nevertheless courted the 'wine vote' by highlighting injustices and inequality: 'wine growers live with 2,700 francs per month, whilst young people drive around in BMWs' ${ }^{70}$ Concurrently, the Front National gained a dramatic 35 per cent of the vote in the first round of the presidential election in Béziers, with Jean Marie Le Pen receiving 3,000 more votes than Jacques Chirac. ${ }^{71}$

In municipal elections, however, this rise was somewhat masked by the tradition of broad platform candidates. The FN had done well in 1995, capturing the mayoralty in Toulon, Orange and Marignane, before the party split, denting its progress. ${ }^{72}$ After the split the subsequent appearance of the National Republican Movement (Mouvement national républicain; MNR) in 1999 did not prove mutually exclusive with the continued existence of the FN, and councillors elected on protest votes cropped up from both parties during Raymond Couderc's mayoralty. One of Couderc's greatest supporters was the president of the region, Jacques Blanc, and although Couderc skirted association with the far right, Blanc had relied on their votes again in 1998, and so lent them an air of respectability. ${ }^{73}$ Amidst political shifts, the wine crisis continued to deepen, changing the region's economic profile and reshaping areas of economic activity. In August 2002, just outside Béziers in Sauvian, the CRAV targeted supermarkets and destroyed bottles of Greek and Italian wine in what they called 'quality control'. ${ }^{74}$ Wine growers remained mobilised. Following a coordinated day of protests across the Languedoc-Roussillon and large marches in Narbonne and Béziers in February 2006, spokesman Phillippe Vergnes demanded the prime minister adopt 'extreme rigour in the face of European institutions in order to defend French vineyards' ${ }^{75}$ CRAV action continued across the Languedoc, with attacks on supermarkets and tax offices across the Hérault signalling imports and taxation remained priority targets. ${ }^{76}$ Regional protests in 2009 described the crisis, which had begun in 2004, as the worst wine growers had ever faced, and as up to 10,000 wine growers protested in Montpellier, raucous demonstrations saw an estimated 1,000 police and CRS deployed in Béziers. ${ }^{77}$ These repeated protests and their shared targets demonstrated the ways in which the continuing wine crisis was hollowing out the constituency of wine growers upon which the politics of the south had long been built.

One of the most symbolic indications of this shift was the conflict surrounding the takeover of the Béziers-Boujan cooperative by its counterpart in Coursan across the departmental boundary in the Aude. The rescue package for the struggling cooperative winery promised to continue operation with minimal job losses but involved the transfer of all its wine making to the Coursan winery. ${ }^{78}$

\footnotetext{
67 Christian Aniort, ‘8.000 à crier leur colère’, La Dépêche, 22 Mar. 2001.

68 'Une écharpe tricolore dans la manifestation: "Conjuguer mon métier et mon rôle d'élu »', La Dépêche, 22 Mar. 2001.

69 Christian Aniort, 'Rien ne va plus chez les vignerons', La Dépêche, 17 Jan. 2002.

70 Benoit Hopkin, 'Le Midi « rouge " risque de basculer à l'extrême droite', Le Monde, 08 June 2002.

71 'Languedoc Roussillon: La vague Le Pen', La Dépêche, 22 Apr. 2002.

72 See Joel Gombin, 'Le changement dans la continuité geographies électorales du Front National depuis 1992', in Crepon et al, Les faux semblants, 395-416. On the mégrétiste split, see Dominique Albertini and David Doucet, Histoire de la Front National (Paris: Tallandier, 2014), 207-36.

73 For a full account of Blanc's election bid, see Yves Pourcher, 'Votez tous pour moi! Les campagnes électorales de Jacques Blanc en Languedoc-Roussillon (1986-2004) (Paris: Presses de Sciences Po, 2004).

74 Richard Lorente, 'L'avertissement viticole', La Dépêche, 22 Aug. 2002.

75 'Viticulteurs: la rue pour déboucher la crise', La Dépêche, 16 Feb. 2006.

76 'Retour sur les dernières actions du CAV en Languedoc-Roussillon', Midi Libre, 17 July 2013.

77 'Plusieurs milliers de viticulteurs réclament des aides pour sortir de la crise', Midi Libre, 25 Nov. 2009.

78 Jean-Pierre Amarger, 'Le président de la cave assure avoir un projet', Midi Libre, 09 June 2011.
} 
This was controversial in Béziers, as the town was seen as the birthplace of cooperative wine making (the Maraussan cooperative in the north-west had been opened by Jean Jaurès in 1905), and so losing control of its last viable cooperative to its Audois neighbours seemed a symbolic marker of decline. ${ }^{79}$ Conscious of the symbolic loss this represented, Raymond Couderc (and his ally Elie Aboudie) tried to halt the move, while nevertheless claiming that it did 'not mean that wine is dead in Béziers' ${ }^{80}$ Despite Couderc's intervention, the merger went ahead, and the amalgamated winery fully opened its doors in $2014{ }^{81}$ This signalled both a symbolic shift in the town's prominence as a capital of the wine growing south (midi viticole), as well as a personal blow to the mayor's own local reputation.

Personal power (and aloofness from national parties) was an important marker of southern politics, emerging from the Midi's distinct political inheritance. Regional political discourse shaped the responses of the left in the 1960s and 1970s, encouraging the PCF to rally to the idea of selfmanagement (autogestion) in the form of regional autonomy, and the PS to abandon much of its centralising heritage locally. ${ }^{82}$ Both parties found success directing protest against central government as a means of expressing regional dissatisfaction. As mentioned, in the 1980s the PS and PCF became less obvious vehicles for protest in the south and instead municipal mavericks challenged party lines to gain support, with personalised models of regional power not hard to find. In Montpellier, Georges Frêche pursued a broadly socialist vision of 'modernising municipal administration' founded on an outspoken personality combined with pragmatism, clientelism and 'an ability to speak different languages to different audiences' ${ }^{83}$ Another example of this personalised style was the great rival of Frêche, Jacques Blanc. Both figures professed a role beyond party structures while clothing themselves in references to the region's heritage. Robert Ménard capitalised on this background of personalised politics in his electoral campaign, injecting a populist nativist line into what Négrier and Jourda describe as the 'regional populism' of Frêche and Blanc. ${ }^{84}$ When Ménard faced up against Couderc in the municipal elections of 2014, therefore, his was not a candidacy that appeared out of the blue. Rather, it came off the back of a long divorce from the left, allied to a discrediting of the region's agents of socialisation (amongst the syndical organisations of mass wine growing and their militant wings).

Béziers's recent political history bred a dissatisfaction with the alliances and electoral platforms that had characterised previous mayoral candidacies, and instead heightened the appeal of a candidate with an anti-systemic message, name recognition and a distinctly different programme. ${ }^{85}$ The decline of wine growing had a long systemic effect on the city, but the recent sale of the Béziers-Boujan cooperative also strengthened this narrative of 'the death of wine in Béziers' ${ }^{86}$ After the death of Frêche, loyalties were split in the region, between those who supported differing lists sponsored by him or the Socialist Party. In the mayoral election of 2014 Couderc's nominated successor was the centre-right Elie Aboud, who had managed to rally people to his cause like the one-time Frêche protégé Agnès Jullian. Aboud took Ménard to the second round in a close-run campaign, before Ménard won with 46.99 per cent of the votes. Ménard's personal campaign was a broad church, appealing to those in the FN, the far-right Bloc identitiaire and even those with sympathies for the extreme-right nationalist Action Française, while functionally aloof from existing political machinery and norms.

79 Jean-Pierre Amarger, 'Une association défend les coopérateurs', Midi Libre, 15 June 2011. On Maraussan, see Smith, Terror and Terroir, 27.

80 'Cave coopérative: fusion ou promo, il faudra choisir', Midi Libre, 16 June 2011.

81 'Premier bilan satisfaisant du mariage d'une cave Audoise et Héraultaise', Midi Libre, 12 June 2013.

82 Jean Sagnes, Le Midi rouge, mythe et réalité: Études d'histoire occitane (Paris: Anthropos, 1982), 304.

83 Emile Chabal, 'Le Président? Georges Frêche and the Making of a Local Notable in Late Twentieth-Century France', in Philip Whalen and Patrick Young, eds., Place and Locality in Modern France (London: Bloomsbury, 2014), $205,214$.

84 Emmanuel Négrier, Marie-Thérèse Jourda and Stéphane Ratinaud, 'Guerre des Roses en Languedoc. Les élections régionales 2010', Pôle Sud, 34, 1 (2011), 64.

85 On the programme’s Poujadist inheritance, see Négrier, et al. 'Guerre des Roses en Languedoc'; Emmanuel Négrier, 'Une vague bleue en Midi Rouge. Les élections 2014 en Languedoc-Roussillon', Pôle Sud, 41, 2 (2014), 203-13; Nicolas Lebourg, 'Le Front National et la galaxie des extrêmes droites radicales', in Crépon et al, Les faux-semblants, 136.

86 'Cave coopérative: fusion ou promo, il faudra choisir', Midi Libre, 16 June 2011. 
Ménard's very loose affiliation to the FN thus strengthened his ability to present himself as a local boy who understood local problems. ${ }^{87}$

The grand protests of 1907 had been a recurring rhetorical feature of regional protest, and thus became a particularly useful historical reference for Ménard in his trumpeting of local heritage. This epochal series of demonstrations had repeatedly lent itself to mythic retelling amongst wine growers. In 1948 Louis Blanc, the former editor of Le Tocsin (the central organising newspaper of the 1907 protests) wrote a pamphlet called Memories of 1907, which associated the struggle with resistance to 'the anonymous forces of the economy. ${ }^{88}$ The next year, the Communist Party produced a short film which juxtaposed 1907 with images of the 1947 strikes at the Renault factory in Boulougne-Billancourt, focusing on the repression of economic forces. That film also highlighted the importance of the story to Béziers politics, recalling deputy for Béziers, Raoul Calas, who was expelled from the chamber in 1947 for publicly exalting the mutiny of the seventeenth infantry regiment to support demonstrators during the 1907 revolt; this history lesson was deemed incendiary while the 1947 strikes were at their peak. ${ }^{89}$ The myth of 1907 was flexible and strongly conditioned the rhetoric of the wine growers' movement as it gathered strength in the 1960s alongside a revived Occitanism, providing numerous opportunities to redeploy the story of the grand revolt. The alliance between Occitan identity and the wine growers' movement in that period conjured up a conscious link to a broader regional struggle rooted in ethnolinguistic identity and promoting the patrimony of a 'civilization of the vine'. ${ }^{90}$ For militant Occitan wine growers, this narrative affirmed that since 1907 their enemies had been 'merchants, political power and the big landowners'. ${ }^{91}$ The decline of mass wine growing did not kill off the myth of 1907, and rebellious rhetoric appealed to those smarting from 'the internalisation of decline' and 'symbolic or material loss'. ${ }^{92}$ That loss, symbolised in the economic transformation of the region, had greatest potency when articulated in the language of regional revolt. At the start of his campaign in 2013, therefore, Ménard emphasised 'true local culture' as being one of the central concerns of his 'Choose Béziers' (Choisir Béziers) platform and recited his own compatible narrative of the region's struggles:

From the Cathars to Jean Moulin to the revolt of the wine makers of 1907, Béziers knew how to say no when it was necessary, when history demanded it, when the conscience demanded it, when freedom imposed it. ${ }^{93}$

Indeed, in an illustration of the potential for these reactionary regional narratives, Ménard trumpeted his endorsement by Phillippe de Villiers, the conservative author and founder of the Puy-du-Fou theme park (a popular tourist attraction that celebrates an image of a royalist, religious, counter-revolutionary France).$^{94}$ Later Ménard would invite de Villiers to promote his most recent books at a 'free speech' themed series of lectures in Béziers (alongside other repeat guests like Eric

\footnotetext{
87 Abel Mestre and Carol Monnot, 'Les réseaux du Front National', in Crépon et al, Les faux-semblants, 61.

88 L. Blanc, Souvenirs de 1907 (Olonzac: CGVM, 1948). Archives Nationales de la France F10/5360.

89 Raymond Lamy (dir.), La Révolte des Gueux (1949). Ciné-archives, Fonds audiovisuel du Parti communiste français et du mouvement ouvrier et démocratique.

90 See Smith, Terror and Terroir, 128-63.

91 Martin, Histoire de la nouvelle gauche paysanne, 137-42.

92 Emmanuel Négrier, 'Le Pen et le peuple. Géopolitiques du vote FN en Languedoc-Roussillon', Pôle Sud, 37, 2 (2012), 165.

93 Robert Ménard, 'Philippe de Villiers apporte son soutien à Robert Ménard', Hérault Tribune, 17 Dec. 2013. Retrieved from [https://www.herault-tribune.com/articles/19565/philippe-de-villiers-apporte-son-soutien-a-robert-menard/] on 15 Apr. 2019.

94 Robert Ménard, 'Philippe de Villiers apporte son soutien à Robert Ménard', Hérault Tribune, 17 Dec. 2013. Retrieved from https://www.herault-tribune.com/articles/19565/philippe-de-villiers-apporte-son-soutien-a-robert-menard/ on 15 Apr. 2019.
} 
Zemmour, a controversial, right-wing, nativist writer). ${ }^{95}$ In an example of how French history could serve contemporary political messages, the Journal de Béziers noted de Villers' book on Joan of Arc told 'a stunningly contemporary history of a people betrayed by its so-called elites'. ${ }^{96}$

After being elected Ménard inaugurated a series of 'frescoes' on the sides of buildings to commemorate Béziers's history. Again, they referenced prominent figures like Jean Moulin as well as a tribute to the revolt of 1907 (featuring Marcelin Albert and a soldier of the mutinous seventeenth regiment). ${ }^{97}$ During his campaign Ménard had focused on the urban environment, and proposed the establishment of a 'house of wines' (maison des vins) in the historic centre that could capitalise on wine tourism, as well as erecting signs that declared 'Béziers world capital of wine'. ${ }^{98}$ This was part of a 'reconnection to the purity' of local traditions, like the Feria, a southern celebration of bull fighting, song and regional culture, which Ménard enthusiastically endorsed (and at which he reinstituted the once traditional mass as part of proceedings). ${ }^{99}$ In 2016, when Ménard opened the festival, he played up the long narrative of the 'civilization of the vine', rooted in the region and its traditions, like the Feria itself:

I have said it often: this is Béziers! And, as you know, the people of Béziers are proud, and they are unbowed. A people who have a thousand years of resistance behind them, from the Cathars to the wine growers of 1907. A people who are part of a civilization, a Christian civilization which has been around for two thousand years and seen plenty of others. A people who have their own identity and who are holding on to it. ${ }^{100}$

When opening the Feria the next year in 2017, he drew on 1907 as a moment of regional pride, celebrating its defiance: 'yes, like you, I love the soldiers of 1907 who refused to fire on their brothers the wine growers, that was exactly 110 years ago, right here in the Allées [Paul Riquet]'. ${ }^{101}$ This recurring connection between the region's history and its present made through allusion to the streets was an important indication of how Ménard's values found roots in regional consciousness.

Those roots were interwoven with Béziers's urban environment, 'they plunge into our smaller alleys, into our greatest monuments. The atmosphere of Béziers is imbued with this very long history'. ${ }^{102}$ As such, the months after his election saw a swiftly implemented series of measures designed to crack down on minor crimes in the city centre, citing the defence of patrimony as a driver for reform. ${ }^{103}$ Ménard announced in February 2015 that municipal police would be armed, and mooted a 'Garde Bitteroise' to defend the streets, claiming a mandate to 'reconquer the city centre street by street, shop by shop'. ${ }^{104}$ This reconquista was designed to dispel the creeping sense of abandon allowed to develop by 'defeatist' politicians. ${ }^{105}$ In office he also opposed the opening of large suburban stores,

\footnotetext{
95 Journal de Béziers [hereafter JDB], 3 (Oct. 2014), 20; JDB, 22 (Nov. 2015), 13; JDB, 46 (Dec. 2016), 17 On Puy-du-Fou and historical memory, see Steven Kaplan, Farewell, Revolution: Disputed Legacies, France, 1789/1989 (Ithaca, NY: Cornell University Press, 1995), 84-111.

96 JDB, 4 (Dec. 2014), 21

$97 J D B, 43$ (Oct. 2016), 10-1.

98 'Béziers / Municipales: économie et emploi, ce que proposent les candidats', Midi Libre, 20/03/2014; JDB (June 2015 ), 18.

99 'Feria : “Une reconnexion à la pureté" sur l'affiche', Midi Libre, 04 June 2016.

100 Robert Ménard, 'Inauguration de la Feria 2016', 11 Aug. 2016. Retrieved from http://www.ville-Béziers.fr/discours-derobert-Ménard-maire-de-Béziers-pregon-inauguration-de-feria-2016/ on 03/09/2018.

101 Ville de Béziers Facebook page, 12 Aug. 2017. Retrieved from: https://www.facebook.com/ville.debeziers/photos/discoursde-robert-m\%C3\%A9nard-lors-du-pregon-nous-voici-ici-comme-chaque-ann\%C3\%A9e-pour-/1519276681444396/ on 15 Apr. 2019.

102 JDB, 48 (Jan. 2017), 4.

103 'A Béziers, Robert Ménard interdit d'étendre le linge aux fenêtres', Le Monde, 20 May 2014 ; 'A Béziers, Robert Ménard prend un arrêté anti-crachats', Le Monde, 20 Sept. 2014.

104 Rémy Cougnenc, 'Béziers: l'envers du décor de la gestion de Robert Ménard', La Marseillaise 10 Dec. 2017; 'Le pistolet semi-automatique, «nouvel ami» de Robert Ménard', Liberation, 11 Feb. 2015; 'La " garde biterroise " de Robert Ménard retoquée en justice', Le Monde, 5 July 2016 ; JDB, 42 (Oct. 2016), 4.

105 $J D B, 42$ (Oct. 2016), 4.
} 
which contributed to the destruction of the city centre and constituted economic 'suicide' for the town. ${ }^{106}$ This spoke to the developing relevance of Viard's model of 'commuter democracy' to Béziers and its political situation, balancing changing urban dynamics with securitised politics. ${ }^{107}$ This form of concocted narrative thus played on concerns of uprooting identity and wine growing heritage, as well as leveraging worries about economic insecurity and powerlessness in the face of external forces. $^{108}$

Béziers, as a result of its wine growing heritage in particular, voted firmly 'no' in both European referendums, in 1992 (56.2 per cent) and 2005 (61.7 per cent). ${ }^{109}$ This marked an endorsement of a long culture of opposition, and in particular flew in the face of regional elites that, in both instances, had favoured a 'yes' vote. ${ }^{110}$ Jacques Blanc, for example, had successfully created a 'social imaginary' which grounded international issues in local referents to establish 'the legitimacy of their spatial definition and at the same time their own right to intervene in defence of specific interests'. ${ }^{111}$ This allowed a cautious engagement with Europe, in which the Midi could play a greater role - reimagining itself in a European context as opposed to a French national one. However, the popular rejection of this is perhaps best understood in the context of the Talgo train hijacking and the written protests in the pages of $L$ 'Echo des Corbieres described earlier. Or, indeed, in the CRAV attacks which continued to target Spanish wine imports, as they did in Béziers in 2016 and 2017. ${ }^{112}$ On Friday 24 March 2017 there were pronounced echoes of the Leclerc attack over thirty years before. The offices of the wine brokerage Vergnes et Passerieux were torched with Molotov cocktails and the offices spray-painted with the name of the CRAV in protest at the import of Spanish wines. ${ }^{113}$ The following day, at a mass rally in Narbonne, Frédéric Rouanet (an Audois wine growers' union leader) called on politicians to defend the sector and the region: 'You can't leave us alone in the face of this profit mania. Was Europe made to protect us or to kill us? ${ }^{114}$ Commenting on the protest, Ménard's mouthpiece, the Journal de Béziers magazine, signalled its support for the wine growers' campaign: 'Béziers, historic capital of wine growing needs to support its wine growers. Beware, globalisation means plonk! ${ }^{115}$ The denunciation of the European Union as distant, technocratic and injurious to national identity had long been FN policy, and was enthusiastically endorsed by Marine Le Pen, who duly topped the first round of the 2017 presidential election in Béziers. ${ }^{116}$ For Ménard, ploughing his own furrow,

106 JDB, 28 (Feb. 2016), 3-7; JDB, 30 (Mar. 2016), 8.

107 To track Ménard's engagement, see R. Ménard, 'Se sentir chez soi', 3 Sept. 2012. Retrieved from http://www. robertMénard.fr/2012/09/03/se-sentir-chez-soi/ 06/12/2013.

108 It also drew some voters from the left, concerned by immigration, and often described as gaucho-lepéniste. For more on this phenomenon, see Pascal Perrineau, Cette France De Gauche Qui Vote FN (Paris: Seuil, 2017).

109 Marie-Thérèse Jourda, Emmanuel Négrier, 'Retour sur le "non " languedocien au traité constitutionnel européen. Le référendum du 29 mai 2005 en Languedoc-Roussillon', Pôle Sud, 23, 2 (2005), 176.

110 Ibid., 177.

111 Smith, 'L’Europe, le Midi et le vin', 132.

112 Liz Alderman, 'Wine War in Southern France Has Streets Running Red', New York Times, 25 Aug. 2017.

113 'Les bureaux d'un courtier en vin à Béziers incendié, le CRAV revendique', Le Figaro, 27 Mar. 2017.

114 'Les vignerons du Midi «jettent une grosse bouteille dans la campagne»', Le Figaro, 26 Mar. 2017.

115 JDB, 54 (Apr. 2017), 20.

116 Emmanuelle Reungoat, 'Le Front National et l'union européenne. La radicalisation comme continuité', in Crépon et al, Les faux-semblants, 233. See also, Gilles Ivaldi, 'Contesting the EU in times of crisis: The Front National and Politics of Euroscepticism in France', Politics, 38, 3 (2018), 278-94. On the ways in which Le Pen has altered the party, see Alexandre Dézé, 'La « dédiabolisation ». Une nouvelle stratégie ?', in Crépon et al., Les faux-semblants, 25. Le Monde described Ménard as a 'torchbearer of the de-diabolized' FN. 'Robert Ménard, porte-flambeau de la dédiabolisation du FN', Le Monde, 20 June 2013. See also Gilles Ivaldi, 'A New Course for the French Radical-Right? The Front National and 'De-Demonization", in Tjitske Akkerman, Sarah L. de Lange, Matthijs Rooduij, eds, Right-wing Populist Parties in Western Europe: Into the Mainstream? (London: Routledge, 2016), 231-53. Ménard certainly exhibits the 'corrupt elite v pure people' trope outlined by Mudde. See, Cas Mudde, 'The Populist Zeitgeist', Government and Opposition, 39, 4 (2004), 543. Ménard certainly claims to be 'of the people but not of the system', as outlined by Taggart. See Paul Taggart, The New Populism and the New Politics: New Protest Parties in Sweden in a Comparative Perspective (London, Macmillan, 1996), 32. Likewise, this 'neo-republican' style seems to create a tension between, on the one hand, a pious commitment to the sanctity constitution, and on the other, a desire to project values upon it, echoing the democratic 
he could in turn lament how 'the French political class had officially abdicated in the face of the ravages of globalisation'. ${ }^{117}$

During Ménard's campaign in 2014 he had tapped into this resentment, straining to make clear his opposition to 'communitarianism' (communautaurisme) ${ }^{118}$ and any resultant threat to the inviolability of the republic, all with coded reference to 'globalist elites' and the voice of the putative ordinary Beziers residents (as when he referred to Béziers as a 'city of resistance' in his appeal to US President Donald Trump to visit the region in 2016). ${ }^{119}$ Such resistance was shown by illegally polling the ethnic composition of primary schools, or championing his display of a Christmas nativity scene in the mayoralty. ${ }^{120} \mathrm{He}$ also, importantly, addressed a strong pied-noir community of which he was a member. ${ }^{121}$ In playing up the threat to local culture, he promoted the idea of a 'grand replacement' - a notion he freely adopted from the far-right Renaud Camus, who posits the gradual dilution and disappearance of French civilization through immigration. ${ }^{122}$ This led him to defend Béziers vociferously against the (humanitarian) impositions of external elites (notably with alarmist posters showing concocted images of migrants). ${ }^{123}$ Railing against abstract forces, like the state, European integration or, indeed, globalisation allowed Ménard to appeal directly to the securitised commuter democracy of the suburbs whilst maintaining the language of regional difference. This focused on Béziers's relative decline because of changes to the wine sector just as it played on the trope of a fragile ethno-national identity. As with the wine growers and Europe, Ménard's references to 1907 and his quest for cultural authenticity blended lingering concerns into a much more compelling narrative around the uprooting of identity.

\section{Conclusion}

The process of political and economic realignment after 1984 affected the Languedoc profoundly, marking a significant turning point. The structures of viticultural representation changed as the wilder elements of the wine growers' defence movement lost ground against rivals readier to support reform and the agency of traditional representative bodies to negotiate change with bigger, impersonal powers like the EEC floundered. By 1992, when accusations of 'wine terrorism' were made by police, and masked protesters were arrested in Béziers, European integration was significantly altering the

tension which creates space for populism. See, Margaret Canovan, 'Trust the People! Populism and the Two Faces of Democracy', Politics 47, 1 (1999), 2-16. Indeed, populist is used here in line with these definitions, and that of Jan Werner-Müller: Ménard's rhetoric has shown itself to be directly engaged with identity politics, repeatedly anti-elitist and anti-pluralist in the personalisation of his platform, and in articulating and defending his notions of threat (to civilisation, security and more). See, Jan Werner- Müller, What is Populism? (London: Penguin, 2017).

117 JDB, 23 (Nov. 2015), 3.

118 Communautaurisme is difficult to translate into English and began to appear regularly in French in the 1980s. It tends to be used to mean group identity politics, often used in a pejorative sense by right-wing cultural commentators and politicians.

119 Ménard subsequently invited Donald Trump to visit him in Béziers, citing their shared belied in the defence of 'families, borders, traditions and the nation, and our fight against globalism and terrorism'. Robert Ménard (@robertMénardfr), Mon invitation au président @realDonaldTrump à venir à \#Béziers, ville de résistance. (9 Nov. 2016). Retrieved from https://twitter.com/RobertMénardFR/status/772760907369836544 on 2 Aug. 2018.

120 Marc de Boni, 'Selon Robert Ménard, 'être Français, c'est être blanc et catholique', Le Figaro 05/09/2016; 'Béziers conserve sa crèche de Noël cette année', Le Monde, 19 Dec. 2014.

121 See Valeria Costa-Kostritsky, 'Tartuffe in Béziers', LRB Blog, 5 Apr. 2016. Retrieved from http://www.lrb.co.uk/blog/2016/ 04/05/valeria-costa-kostritsky/tartuffe-in-Béziers/ on 3 Sept. 2018; see also, 'Le vote pied-noir : mythe ou réalité ?', IFOP Focus Département Opinion et Stratégies d'Entreprises, 107 (Mar. 2014), 7

122 Robert Ménard (@robertMénardfr), \#rentreedesclasses: la preuve la plus éclatante du \#GrandRemplacement en cours. Il suffit de regarder d'anciennes photos de classe... (1 Sept. 2016). Retrieved from https://twitter.com/RobertMénardFR/status/771404889754927104 on 2 Aug. 2018. See Hugo Frey, 'Contradiction Without End: Renaud Camus and the Parti de l'In-nocence', in Ralph Sarkonak, ed., Les Spirales du sens chez Renaud Camus (Leiden: Brill, 2009), 207-31.

123 Laurence Lemouzy, 'L'imaginaire dans l'action publique territoriale' (Unpublished PhD Thesis, Université Paris II, 2017), $361-4$. 
economic activity and the physical landscape of the region. ${ }^{124}$ The sector's decline was not solely because of European integration and the Common Agricultural Policy, instead owing more to changing domestic consumption patterns. Yet, in protesting against this trend and its painful consequences for the Languedoc, Europe became a more effective scapegoat as Paris passed the buck. Against this backdrop, the development of the FN benefitted from a broad group of voters forced to reckon with pronounced negative change to an industry with a long and proud heritage. Cultures of protest adapted and changed, though they did not disappear. The ability of Robert Ménard to capitalise upon this trend in Béziers was an example of how the growth of a suburban electorate coupled with economic decline could be addressed with 'shared symbolic references' borrowed from the vineyards only decades earlier, yet shaped for the ear of a new 'commuter democracy'. ${ }^{125}$

'Why come back to the past?' Ménard asked at a speech in 2016. 'Because the past flows into the future. Everything comes back.' ${ }^{\text {, }}$ The past to which he was referring wasn't the sectoral change or demographic shifts since the 1980s that contributed to his election, but the platform for a populist 'gaucho-lepéniste' (supporting Le Pen from the traditional left) appeal binding the resentment of regional hardship to issues of national concern and suffused with symbols of the past. His focus on the urban environment of Béziers appealed to the sense that the city was in decline from its former position as a wine growing capital, and his tussles with external powers (be they Europe or the French government) were a bid to assert agency. His concocted vision of the long past offered a shortcut around the difficult political realities of the recent past, channelling cultures of opposition which had been stifled and activating insecurities about declining status and future development. The interaction of wine and politics provided the vocabulary to negotiate this broader shift in identity. Understanding the Leclerc fire and the Dublin Accords as steps on the road to an altered political reality puts the emphasis on how the decline of wine production in the region was part of a broader untangling of regional alliances, and shifts Ménard's victory towards its sectoral and demographic determinants and away from notions of cultural backlash.

Acknowledgements. Thanks are due to colleagues and friends who read over drafts of this article, particularly Hugo Frey, Alex Sutton and Andrew Dodd. This article was first explored at a conference on populism organised by Harry Stopes and Alex DeArcangelis, and subsequently at the IHR Modern French History Seminar, and thanks are due to attendees at both for comments. Thanks also to Pierre Purseigle for sympathetically chairing a panel in which I delivered a paper about the city of his birth, offering invaluable commentary afterwards. I am grateful to the staff at Lo Cirdoc in Béziers for helping to guide me through their collections.

\footnotetext{
124 Smith, Terror and Terroir, 262.

125 Touzard, 'Regulation sectorelle', 318; Viard, Béja, Mongin, 'Marseille, Maritime Et Cosmopolite', 91.

126 Costa-Kostritsky, 'Tartuffe in Béziers'.
}

Cite this article: Smith AWM (2020). Uprooting Identity: European Integration, Political Realignment and the Wine of the Languedoc, 1984-2014. Contemporary European History 29, 473-487. https://doi.org/10.1017/S0960777320000387 